\title{
Production of Piptadenia stipulacea (Benth.) Ducke seedlings irrigated with fish farming wastewater
}

\author{
João P. N. de Almeida ${ }^{1}$, Rômulo M. O. de Freitas ${ }^{2}$, Narjara W. Nogueira ${ }^{1}$, \\ Francisco de A. de Oliveira ${ }^{1}$, Hugo Ferreira ${ }^{1} \&$ Moadir de S. Leite ${ }^{1}$ \\ ${ }^{1}$ Universidade Federal Rural do Semi-Árido/Centro de Ciências Agrárias. Mossoró, RN. E-mail: joaopaulonobre@yahoo.com.br; narjaranogueira@ufersa.edu.br; \\ thikaoamigao@ufersa.edu.br; hugopinheiro35@gmail.com; moadir@outlook.com \\ ${ }^{2}$ Instituto Federal de Educação, Ciência e Tecnologia Baiano/Campus Valença. Valença, BA. E-mail: romulomagno_23@hotmail.com (Corresponding author)
}

Key words:

'jurema-branca'

water reuse

propagation

\begin{abstract}
A B S T R A C T
The objective of this study was to evaluate the growth of 'jurema-branca' seedlings (Piptadenia stipulacea (Benth.) Ducke.), irrigated with effluent from fish farming in order to meet the nutritional demand in the initial growth stage. The treatments consisted in the dilution of fish farming wastewater in different concentrations $(0,25,50,75$ and $100 \%)$ with supply water. Seeds were sown in 0.9 -L polyethylene bag containing a mixture of soil and manure. At 54 days after sowing the shoot length, stem diameter, height/diameter ratio, number of leaves, leaf area, unit leaf area, dry matter of stem, leaves, shoots, roots and total, chlorophyll content index and Dickson quality index were evaluated. The growth of 'jurema-branca' seedlings is favored by the dilution of $25 \%$ of fish farming wastewater in the supply water. Using up to $25 \%$ of the concentration of the fish farming effluent does not significantly affect the dry biomass accumulation in 'jurema-branca' seedlings, in relation to the control. The reuse of fish farming wastewater diluted at proportion of up to $25 \%$ is a viable alternative to meet the water demand in the production of forest seedlings.
\end{abstract}

Palavras-chave:

jurema-branca reuso de água propagação

\section{Produção de mudas de Piptadenia stipulacea (Benth.) Ducke irrigadas com água residuária da piscicultura}

\begin{abstract}
R E S U M O
Objetivou-se, com este trabalho, avaliar o crescimento de mudas de jurema-branca (Piptadenia stipulacea (Benth.) Ducke.), irrigadas com efluente da piscicultura visando suprir a demanda nutricional na fase inicial de crescimento. Os tratamentos se constituíram da diluição de água residuária da piscicultura em diferentes concentrações $(0,25,50,75$ e $100 \%$ ) com água de abastecimento. A semeadura foi realizada em saco de polietileno de $0,9 \mathrm{~L}$ contendo uma mistura de solo e esterco. Aos 54 dias após a semeadura foram avaliados o comprimento da parte aérea, o diâmetro do caule, a razão altura/diâmetro, o número de folhas, a área foliar, a área foliar unitária, a massa seca do caule, da folha, da parte aérea, da raiz e total, o índice do conteúdo de clorofila e o índice de qualidade de Dickson. O crescimento de mudas de jurema-branca é favorecido com a diluição de $25 \%$ de água residuária da piscicultura na água de abastecimento. O uso de até $25 \%$ da concentração do efluente da piscicultura não afeta de forma significativa o acúmulo de biomassa seca em mudas de jurema-branca em relação à testemunha. O reaproveitamento da água da piscicultura diluída em proporção de até $25 \%$ é uma alternativa viável para suprir a demanda hídrica na produção de mudas florestais.
\end{abstract}




\section{INTRODUCTION}

Over the last years, the Brazilian semi-arid region has suffered environmental impacts because of the unsustainable exploitation of its natural resources. The interest in the propagation of forest seedlings and in the viability of using wastewaters as water source is increasing because of the necessity to recover degraded areas.

For the forest recomposition of degraded areas, Piptadenia stipulacea (Benth.) Ducke. belonging to the Fabaceae family, also known as 'jurema-branca', is a small-size arboreal species, native to the Caatinga, with wide distribution in the Northeast region of Brazil and of great commercial, economic and environmental interest (Maia, 2012).

One of the types of wastewater is that resulting from fish farming waste, which has large amount of dissolved mineral nutrients and that is disposed in water sources (Silva et al., 2014), which can cause environmental damages because of the high salt contents. The fertilizing effect of the wastewater from fish farming can be advantageous in the production of commercial seedlings (Castro et al., 2006; Freitas et al., 2008; Medeiros et al., 2008). A negative point of this waste is that its high salinity can reduce plant growth, as observed by Pinto et al. (2016), working with Tabebuia aurea.

Thus, the present study aimed to evaluate the growth of 'jurema-branca' plants irrigated with fish farming effluent.

\section{Material ANd Methods}

The experiment was conducted from June to August 2013, in a greenhouse, at the Department of Plant Science of the Federal Rural University of the Semi-Arid Region (UFERSA), in Mossoró-RN, Brazil (5 $5^{\circ} 11^{\prime} \mathrm{S} ; 37^{\circ} 20^{\prime} \mathrm{W} ; 18 \mathrm{~m}$ of altitude). During the experimental period, the mean temperature was $28.5^{\circ} \mathrm{C}$ and the relative air humidity was $68.3 \%$, in a nursery with $50 \%$ shading.

The 'jurema-branca' seeds, from ripe fruits (dry pods), were collected from adult matrix trees present in the UFERSA central campus. After the collection, the fruits were taken to the laboratory, processed, dried in the shade for six days and stored in cold chamber with control of humidity and temperature until the installation of the experiment. Before sowing, the dormancy of the seeds was broken by removing the tip, according to the recommendations of Farias et al. (2013).
The experiment was conducted in the randomized block experimental design composed of five treatments and five replicates, and the experimental plot consisted of four plants. The treatments consisted in the dilution of the fish farming wastewater collected in the aquaculture sector of the Department of Animal Science of the UFERSA, in water from the supply of the UFERSA central campus at different concentrations: T1 - $0 \%$ of wastewater, T2 - 25\% of wastewater, T3 - 50\% of wastewater, T4 - 75\% of wastewater and T5 $100 \%$ of wastewater. The physicochemical characterization (EMBRAPA, 2009) of the irrigation waters used in the experiment is presented in Table 1.

Sowing was performed directly, by placing three seeds in each 0.9-L black polyethylene bag containing a mixture of soil and manure $(3: 1)$. The chemical analysis of the substrate (EMBRAPA, 2009) is shown in Table 2. At 14 days after sowing, thinning was performed, leaving the most vigorous plant in each bag, and plants started to be irrigated with the respective water according to each treatment. Irrigations were daily applied with water volume sufficient to maintain the soil at field capacity, approximately $100 \mathrm{~mL} \mathrm{plant}^{-1}$.

At 54 days after sowing (DAS), the following variables were evaluated: shoot length (SL), stem diameter (SD), height/diameter ratio (H/D), leaf area (LA), unit leaf area (ULA), dry matters of stem (StDM), leaves (LDM), shoots (ShDM), roots (RDM) and total (TDM), chlorophyll content index (CCI) and Dickson quality index (DQI).

Seedling height was measured using a ruler graduated in $\mathrm{cm}$, while stem diameter was measured using a digital caliper, with values expressed in $\mathrm{mm}$. Leaf area was calculated using the disc method, according to the recommendations of Souza et al. (2012), and DQI according to Dickson et al. (1960), in which DQI = [total dry matter/(shoot height/ stem diameter ratio + shoot dry matter/root dry matter ratio)]. The chlorophyll content index (CCI) was determined using a portable chlorophyll meter, CCM-200 (OptiSciences, Tyngsboro, Massachusetts, USA). For dry matter quantification, the plants were divided into leaves, roots and stems, and dried in a forced-air oven at $65{ }^{\circ} \mathrm{C}$ until constant weight. Then, the material was weighed on a precision scale, with results expressed in $g$ seedlings ${ }^{-1}$. In addition, the dry matters of these plant parts were summed to determine the total dry matter.

For the statistical analyses, the obtained data were subjected to the Shapiro-Wilk test to evaluate the normality

Table 1. Physicochemical characterization of the irrigation waters used in the experiment

\begin{tabular}{|c|c|c|c|c|c|c|c|c|c|c|c|}
\hline \multirow{2}{*}{ Treatments } & \multirow{2}{*}{ pH } & \multirow{2}{*}{$\begin{array}{c}E C \\
\left(\mathrm{dS} \mathrm{m}^{-1}\right)\end{array}$} & \multicolumn{3}{|c|}{ Anions $\left(\mathrm{mmol}_{\mathrm{c}} \mathrm{L}^{-1}\right)$} & \multicolumn{4}{|c|}{ Cations $\left(\mathrm{mmol}_{\mathrm{c}} \mathrm{L}^{-1}\right)$} & \multirow{2}{*}{$\begin{array}{c}\text { SAR* }^{*} \\
\left(\mathrm{mmol} \mathrm{L}^{-1}\right)^{0.5}\end{array}$} & \multirow{2}{*}{ Class } \\
\hline & & & $\mathrm{CO}_{3}$ & $\mathrm{HCO}_{3}$ & $\mathrm{Cl}$ & $\mathrm{Mg}$ & $\mathrm{Ca}$ & $\mathrm{Na}$ & $\mathbf{K}$ & & \\
\hline T1 & 7.85 & 0.54 & 1.10 & 2.95 & 2.50 & 0.93 & 0.63 & 9.75 & 10.35 & 11.04 & C2S2 \\
\hline $\mathrm{T} 2$ & 8.25 & 1.56 & 1.20 & 2.80 & 8.90 & 3.59 & 3.31 & 22.50 & 15.55 & 12.11 & C2S2 \\
\hline T3 & 8.15 & 2.52 & 0.70 & 2.85 & 15.90 & 6.01 & 6.13 & 31.65 & 20.25 & 12.85 & C4S2 \\
\hline T4 & 8.15 & 3.44 & 1.00 & 3.55 & 22.20 & 10.30 & 8.55 & 42.90 & 28.30 & 13.97 & C4S2 \\
\hline T5 & 8.25 & 4.25 & 1.10 & 3.30 & 29.00 & 13.83 & 11.04 & 53.40 & 36.90 & 15.14 & C4S2 \\
\hline
\end{tabular}

*SAR - Sodium adsorption rate; SAR $=\mathrm{Na}^{+} /\left[\left(\mathrm{Ca}^{2+}+\mathrm{Mg}^{2+}\right) / 2\right]^{1 / 2}$

Table 2. Chemical analysis of the substrate used in the production of the seedlings

\begin{tabular}{|c|c|c|c|c|c|c|c|c|c|c|c|c|c|c|c|c|c|c|c|c|}
\hline N & OM & \multirow{2}{*}{$\begin{array}{c}\text { EC } \\
d S \mathrm{~m}^{-1}\end{array}$} & \multirow{2}{*}{$\begin{array}{c}\mathrm{pH} \\
\text { (water) }\end{array}$} & $\mathbf{P}$ & $\mathrm{K}^{+}$ & $\mathrm{Na}^{+}$ & $2+$ & $\mathrm{Ma}^{2+}$ & $\mathrm{nl}^{3+}$ & & SB & $\mathrm{T}$ & CEC & V & M & ESP & $C_{1}$ & $\mathrm{Fe}$ & Mn & Zn \\
\hline \multicolumn{2}{|c|}{$\mathrm{g} \mathrm{kg}^{-1}$} & & & & $g d$ & & \multicolumn{7}{|c|}{$\mathrm{cmol}_{\mathrm{c}} \mathrm{dm}^{-3}$} & \multicolumn{3}{|c|}{$\%$} & \multicolumn{4}{|c|}{$\mathrm{mg} \mathrm{dm}^{-3}$} \\
\hline 35 & 11.36 & 0.13 & 8.28 & 25.8 & 98.8 & 95 & 3.20 & 0.48 & 0 & 0 & 4.35 & 4.35 & 4.35 & 100 & 0 & 10 & 0.06 & 2.2 & 11.3 & 3.63 \\
\hline
\end{tabular}


of the distribution. When the data were normal, variance analysis (ANOVA) was applied. Variables with significant response to the treatments were subjected to polynomial regression analysis $(p<0.05)$. The ANOVA and regression analyses were performed using the program Assistat 7.7 (Silva \& Azevedo, 2016).

\section{Results AND Discussion}

The application of fish farming effluent had significant effect on most of the analyzed variables, except stem diameter, which showed a mean value of $1.77 \mathrm{~cm}$.

One of the first symptoms of the influence of salt stress occurs in the leaf growth rate. Irrigation with $25 \%$ of wastewater promoted increase in total leaf area (Figure 1A), as well as in unit leaf area (Figure 1B) in comparison to the control, with maximum values of 90.9 and $11.5 \mathrm{~cm}^{2}$ obtained at the concentrations of 29 and $36 \%$ of wastewater, respectively. These values represent increments of 9.8 and $12.6 \%$, respectively, compared with the control. The values obtained for irrigation with $50 \%$ of wastewater, for these variables, are slightly superior to those obtained in the control and, from this point on, there was a reduction in relation to the control.

According to Medeiros et al. (2010) and Costa et al. (2012), the use of fish farming wastewater in irrigation has effects on the seedlings, causing an increase in the number of leaves, which indicates tolerance of the species to the stress caused by the salts. Such tolerance can also result from the influence of the increments of nutrients present in the wastewater (Table 1). On the other hand, the influence of the residual concentration from $75 \%$ on the leaf area can be related to increasing levels of $\mathrm{Na}$, and values above $42.90 \mathrm{mg} \mathrm{dm}^{-3}$ of this nutrient are harmful to the plants, altering the electrical conductivity of the solution to $3.44 \mathrm{dS} \mathrm{m}^{-1}$, which led to an increase of more than $537 \%$ in comparison to supply water. The excess of sodium salts causes a generalized reduction in the growth of the cultivated plants, leading to serious damages to the agricultural activity (Cavalcante et al., 2010). The decrease in leaf area works as an adaptive mechanism of the plant to the salt stress, reducing its transpiring surface (Tester \& Davenport, 2003).

The increase in the concentration of the wastewater negatively influenced shoot length (Figure 2A), with linear reduction as the proportion of wastewater in the irrigation water increased. These results can be explained by the negative effects of water salinity, which reach high levels at the concentrations of 50,75 and $100 \%$, with reductions in shoot growth of $10.8,16.3$ and $21.6 \%$, at the saline levels of $2.52,3.44$ and $4.25 \mathrm{dS} \mathrm{m}^{-1}$ (Table 1), respectively.

Similar results were observed by Freitas et al. (2010), working with seedlings of Caesalpinea ferrea Benth. These authors observed reduction in seedling height as the salinity increased, with greater effect at the concentrations of 3.0
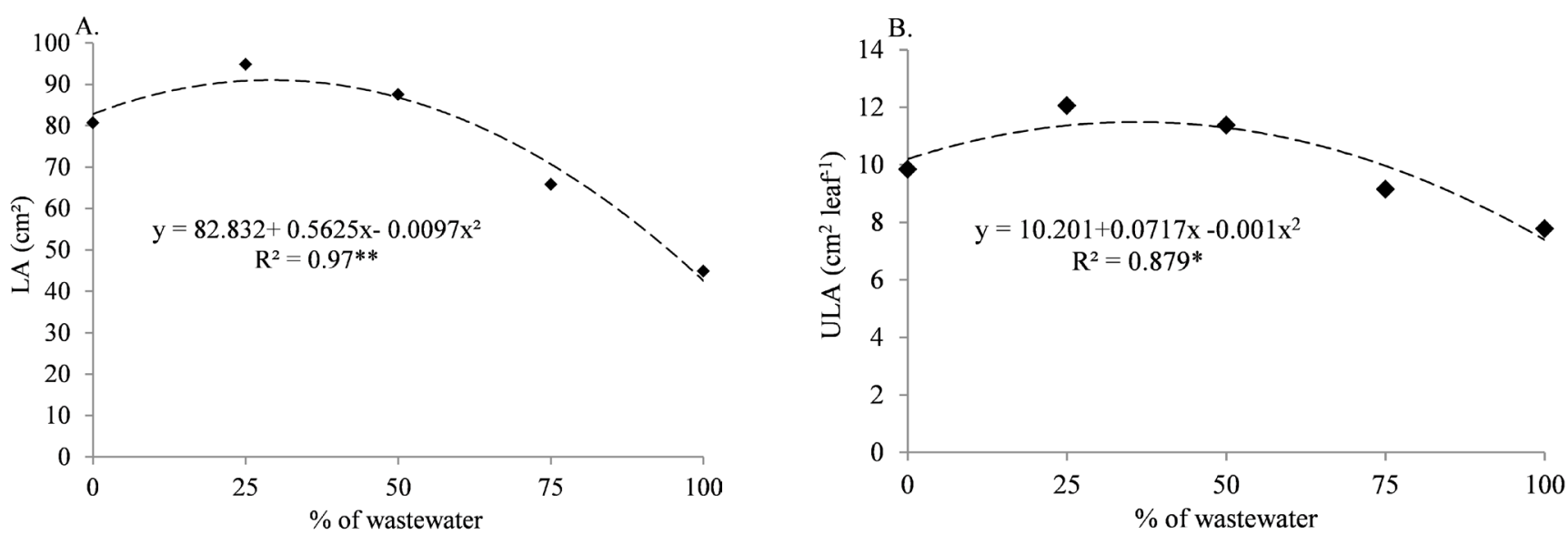

Figure 1. Leaf area (LA) (A) and unit leaf area (ULA) (B) of 'jurema-branca' [Piptadenia stipulacea (Benth.) Ducke.] seedlings irrigated with different dilutions of fish farming wastewater
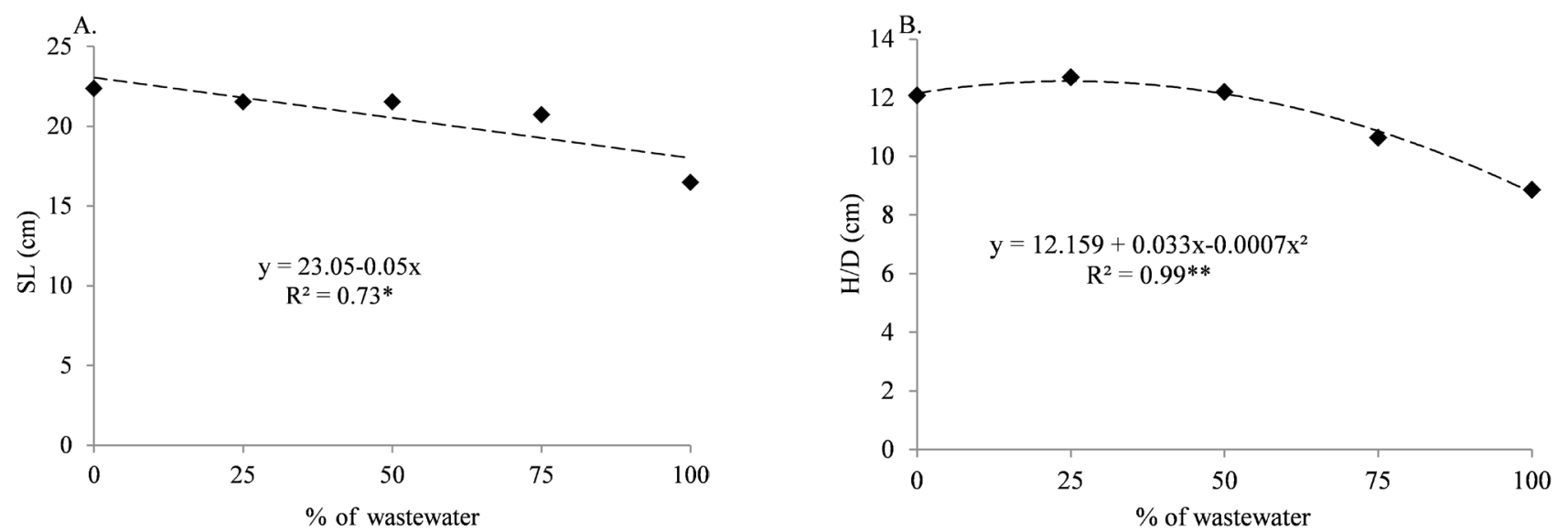

Figure 2. Shoot length (SL) (A) and height/diameter ratio (H/D) (B) of 'jurema-branca' (Piptadenia stipulacea (Benth.) Ducke.) seedlings irrigated with different dilutions of fish farming wastewater 
and $4.5 \mathrm{dS} \mathrm{m} \mathrm{m}^{-1}$. Guimarães et al. (2013) also reported linear reduction for the growth variables of 'mulungu' seedlings as the salinity level of the irrigation water increased.

For the height/diameter ratio (H/D), using $25 \%$ of wastewater led to higher values, with gains of $3.2 \%$ in relation to the control. Concentrations of up to $50 \%$ did not cause reductions (Figure $2 \mathrm{~B}$ ), despite the salts present in the solution. A probable explanation for this effect is that the water from fish farming waste can contribute to the nutrition of the seedlings, considering that the effluent is rich in nitrogen and phosphorus, which are essential elements for plant development. According to Nunes (2002), the fertilizers used in the cultivation of aquatic organisms can increase the concentrations of nitrogen and phosphorus in the water, which can favor the production of tomato seedlings.

The dry matter accumulation in leaves (Figure 3A), stem (Figure 3B), shoots (Figure 3C), roots (Figure 3D) and total (Figure 3E) showed similar responses with the increment in the wastewater concentration in the irrigation of the seedlings. The highest losses occurred for root dry matter (57\%) and leaf dry matter (53\%), while stem dry matter exhibited a reduction of only $2.2 \%$, when only wastewater $(100 \%)$ was used to irrigate the seedlings.

Although the values obtained for these variables fitted to a linear model, there was a small reduction when plants were irrigated with concentrations of $25 \%$ of wastewater. Thus, using wastewater diluted at low doses can be a viable alternative for the irrigation of 'jurema-branca'.

On the other hand, the reduction in biomass accumulation with wastewater concentrations from $50 \%$ on can be attributed to the salinity of the water with electrical conductivity from $2.52 \mathrm{dS} \mathrm{m}^{-1}$ on. These results are similar to those found by Guimarães et al. (2013), in which the studies to test salinity levels on the initial development of 'mulungu' plants showed that the species suffered abrupt reductions in the total dry matter accumulation when irrigated with water of electrical conductivity above $2.5 \mathrm{dS} \mathrm{m}^{-1}$.

This behavior is possibly due to the increment of salts with the mixture of fish farming effluent and supply water, since it is common to observe morphological and physiological alterations in the plants that cause reductions in growth (Taiz $\&$ Zeiger, 2013) and, consequently, in dry biomass.

The treatment that promoted highest Dickson quality index (Figure 4A), close to that of the control, was the concentration of $25 \%$ of wastewater, small reduction of the index. From this point on, there was a sharp decrease with the increase in the percentage of wastewater in the irrigation water. The quality of 'jurema-branca' seedlings decreased as a function of water salinity, a response also observed by Diniz Neto et al. (2014) in seedlings of 'oiticica' (Licania rigida Benth.).

As the wastewater concentrations in the irrigation water increased, the chlorophyll content index increased linearly (Figure 4B), and the application of $100 \%$ of wastewater showed the best indices, with an increment of more than $31.6 \%$ in comparison to the supply water. Such increase in the chlorophyll content in response to the increment in salinity can also be attributed to the effect of concentration, since reductions in leaf matter are common under salt stress (Silva et al., 2011; Oliveira et al., 2011).
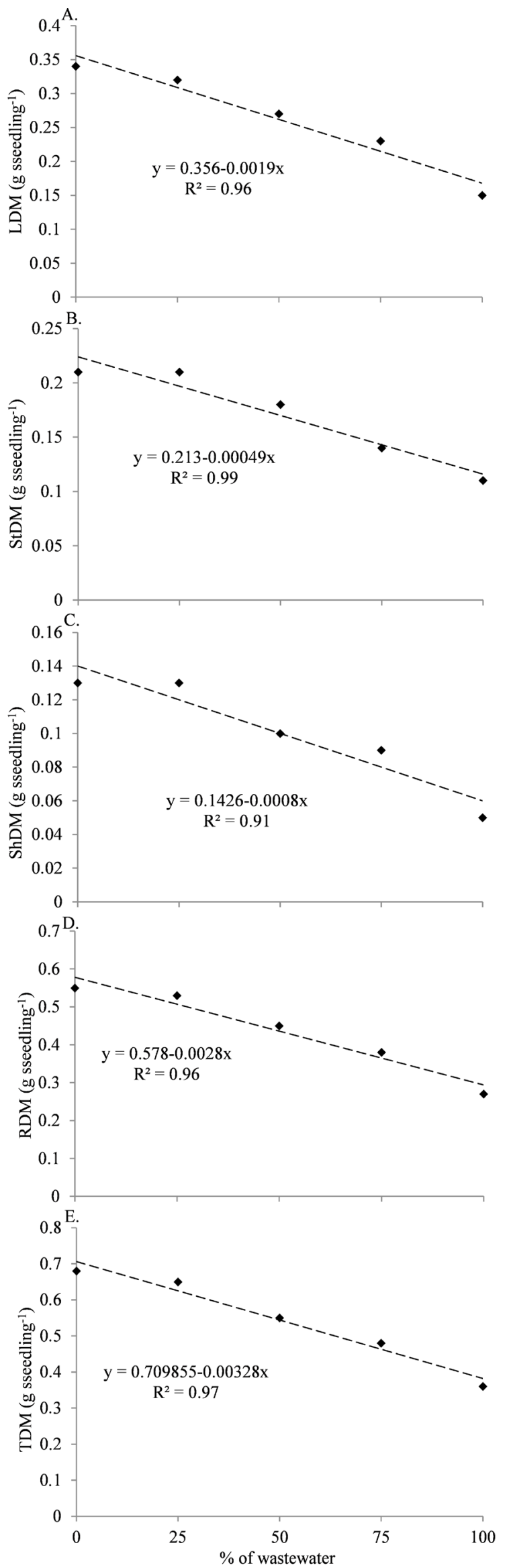

Figure 3. Dry matter of leaves (LDM) (A), stem (StDM) (B), shoots (ShDM) (C), roots (RDM) (D) and total (TDM) (E) of 'jurema-branca' (Piptadenia stipulacea (Benth.) Ducke.) seedlings irrigated with different dilutions of fish farming wastewater 

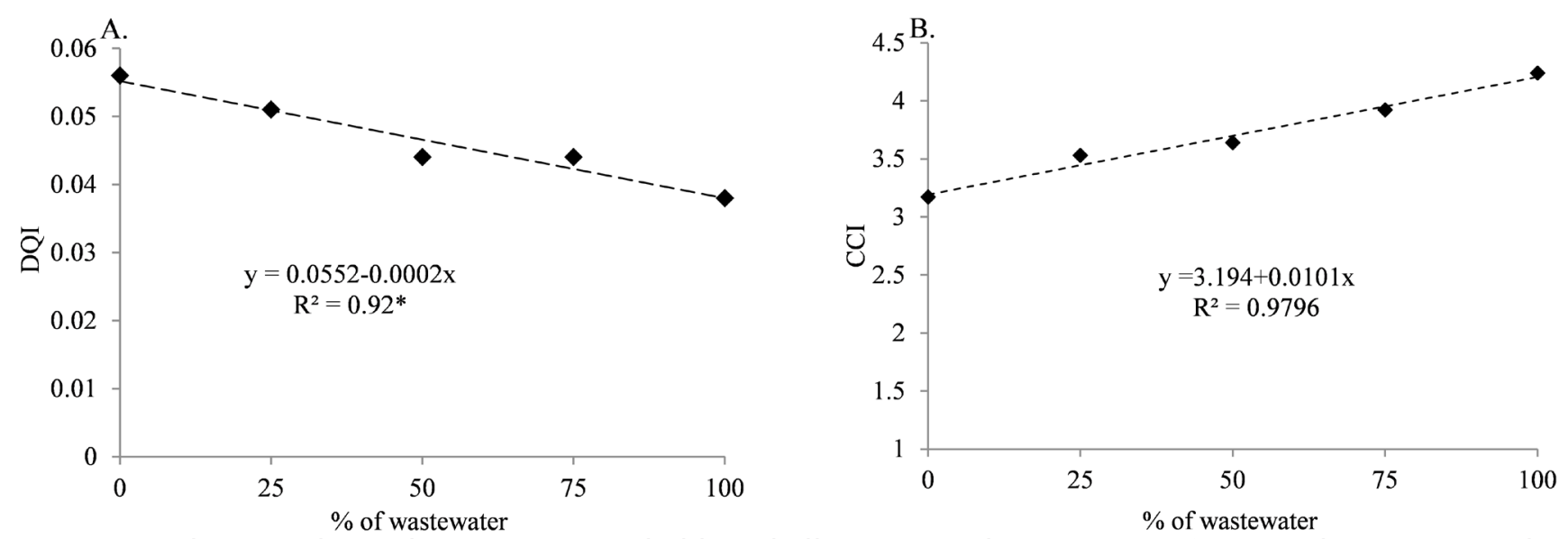

Figure 4. Dickson quality index (DQI) (A) and chlorophyll content index (CCl) (B) of 'jurema-branca' [Piptadenia stipulacea (Benth.) Ducke.] seedlings irrigated with different dilutions of fish farming wastewater

It is important to point out that, as the leaf area increases, the chlorophyll content per $\mathrm{cm}^{2}$ of leaf decreases. These effects were observed at low concentrations of the fish farming effluent. These results are emphasized by Mendonça et al. (2010), who claim that, under saline conditions, the levels that result in greater leaf area and dry biomass are related to the lower yield of the photosystem II (Fv/Fm) and lower concentration of chlorophyll in the leaves.

The reuse of the water from fish nurseries allows the utilization of the water resources and agricultural exploitation (Gomes et al., 2012), and the application of an adequate proportion of this effluent in the production of seedlings of forest species can be considered as a promising alternative for their nutrition and with reduction in the use of supply water, a positive aspect for the environment and semi-arid regions, where water scarcity is increasingly limiting.

\section{Conclusions}

1. The growth of 'jurema-branca' seedlings is favored by the dilution of $25 \%$ of fish farming wastewater in supply water.

2. Using up to $25 \%$ of the concentration of fish farming effluent does not significantly affect dry biomass accumulation in 'jurema-branca' seedlings, compared with the control.

3. The reuse of fish farming wastewater diluted at proportion of up to $25 \%$ is a viable alternative to meet the water demand in the production of forest seedlings.

\section{Literature Cited}

Castro, R. S.; Azevedo, C. M. S. B; Bezerra-Neto, F. Increasing cherry tomato yield using fish effluent as irrigation water in Northeast Brazil. Scientia Horticulturae, v.110, p.44-50, 2006. https://doi. org/10.1016/j.scienta.2006.06.006

Cavalcante, L. F.; Cordeiro, J. C.; Nascimento, J. A. M.; Cavalcante, I. H. L.; Dias, T. J. Fontes e níveis da salinidade da água na formação de mudas de mamoeiro cv. Sunrise solo. Semina: Ciências Agrárias, v.31, p.1281-1290, 2010. https://doi.org/10.5433/16790359.2010v31n4Sup1p1281

Costa, L. R. da; Gurgel, M. T.; Alves, S. M. C.; Mota, A. F.; Azevedo, J. de; Almeida, J. P. N. de. Crescimento de mudas de cajueiro anão precoce irrigado com efluente doméstico tratado. Revista Brasileira de Ciências Agrárias, v.7, p.421-426, 2012. https://doi. org/10.5039/agraria.v7i3a1562
Dickson, A.; Leaf, A. L.; Hosner. J. F. Quality appraisal of white spruce and white pine seedling stock in nurseries. Forest Chronicles, v.36, p.10-13, 1960. https://doi.org/10.5558/tfc36010-1

Diniz Neto, M. A.; Silva, I. de F. da; Cavalcante, L. F.; Diniz, B. L. M. T.; Silva; J. C. A. da; Silva, E. C. da. Mudas de oiticica irrigadas com águas salinas no solo com biofertilizante bovino e potássio. Revista Brasileira de Engenharia Agrícola e Ambiental, v.18, p.1018, 2014. https://doi.org/10.1590/S1415-43662014000100002

EMBRAPA - Empresa Brasileira de Pesquisa Agropecuária. Manual de análises químicas de solos, plantas e fertilizantes. 2.ed. Brasília: Embrapa Informação Tecnológica, 2009. 627p.

Farias, R. M. de; Freitas, R. M. O. de; Nogueira, N. W.; Dombroski, J. L. D. Superação de dormência em sementes de jurema-branca (Piptadenia stipulacea). Revista Ciência Agraria, v.56, p.160-165, 2013. https://doi.org/10.4322/rca.2013.024

Freitas, A. V. L.; Medeiros, M. A. de; Guimarães, I. P.; Madalena, J. A. da S.; Maracajá, P. B. Produção de mudas de pimentão em função do tipo de bandeja e água de irrigação. Revista Verde de Agroecologia e Desenvolvimento Sustentável, v.3, p.106-109, 2008.

Freitas, R. M. O. de; Nogueira, N. W.; Oliveira, F. N. de; Costa, E. M. da; Ribeiro, M. C. C. Efeito da irrigação com água salina na emergência e crescimento inicial de plântulas de Jucá. Revista Caatinga, v.23, p.54-58, 2010.

Gomes, E. R.; D’Albuquerque Júnior, B. S.; Brito, R. R. de. Análise econômica no uso da água de piscicultura na irrigação da banana. Fórum Ambiental da Alta Paulista, v.8, p.16-30, 2012. https://doi. org/10.17271/198008278112012348

Guimarães, I. P.; Oliveira, F. N. de; Vieira, F. E. R.; Torres, S. B. Efeito da salinidade da água de irrigação na emergência e crescimento inicial de plântulas de mulungu. Revista Brasileira de Ciências Agrárias, v.8, p.137-142, 2013. https://doi.org/10.5039/agraria. v8ila2360

Maia, N. G. Caatinga: Árvores e arbustos e suas utilidades. 2.ed. São Paulo: D \& Z. Computação Gráfica e Editora, 2012. 413p.

Medeiros, D. C. de; Freitas, K. C. de S.; Veras, F. de S.; Anjos, R. S. B. dos; Borges, R. D.; Cavalcante Neto, J. G.; Nunes, G. H. de S.; Ferreira, H. A. Qualidade de mudas de alface em função de substratos com e sem biofertilizante. Horticultura Brasileira, v.26, p.186-189, 2008. https://doi.org/10.1590/S010205362008000200011 
Medeiros, D. C. de; Marques, L. F.; Dantas, M. R. da S.; Moreira, J. N.; Azevedo, C. M. da S. B. Produção de mudas de meloeiro com efluente de piscicultura em diferentes tipos de substratos e bandejas. Revista Brasileira de Agroecologia, v.5, p.65-71, 2010.

Mendonça, A. V. R.; Carneiro, J. G. de A.; Freitas, T. A. S. de; Barroso, D. G. Características fisiológicas de mudas de Eucalyptus spp submetidas a estresse salino. Ciência Florestal, v.20, p.255-267, 2010. https://doi.org/10.5902/198050981850

Nunes, A. J. P. Tratamentos de efluentes e recirculação de água na engorda de camarão marinho. Revista Panorâmica da Aquicultura, v.12, p.27-39, 2002.

Oliveira, F. de A. de; Carrilho, M. J. S. de O.; Medeiros, J. F. de; Maracajá, P. B.; Oliveira, M. K. T. de. Desempenho de cultivares de alface submetidas a diferentes níveis de salinidade da água de irrigação. Revista Brasileira de Engenharia Agrícola e Ambiental, v.15, p.771-777, 2011. https://doi.org/10.1590/S141543662011000800002

Pinto, J. R. de S.; Freitas, R. M. O. de; Leite, T. de S.; Oliveira, F. A. de; Ferreira, H.; Leite, M. de S. Growth of young Tabebuia aurea seedlings under irrigation with wastewater from fish farming. Revista Brasileira de Engenharia Agrícola Ambiental, v.20, p.519-524, 2016. https://doi.org/10.1590/1807-1929/agriambi. v20n6p519-524
Silva, A. O. da; Silva, D. J. R. da; Soares, T. M.; Silva, E. F. de F. e; Santos, N. A. dos; Rolim, M. M. Produção de rúcula em sistema hidropônico NFT utilizando água salina do Semiárido-PE e rejeito de dessalinizador. Revista Brasileira de Ciências Agrárias, v.6, p.147-155, 2011. https://doi.org/10.5039/agraria.v6i1a929

Silva, E. A. da; Ramos, J. D.; Silva, F. O. dos R.; Soares, F. M.; Santos, V. A. dos; Ferreira, E. A. Adição de água residuária de laticínio em substrato para produção de mudas de maracujazeiro 'amarelo'. Revista Agrarian, v.7, p.49-59, 2014.

Silva, F. de A. S. e; Azevedo, C. A. V. de. The Assistat Software Version 7.7 and its use in the analysis of experimental data. African Journal of Agricultural Research, v.11, p.3733-3740, 2016. https://doi. org/10.5897/AJAR2016.11522

Souza, M. S. de; Alves, S. S. V.; Dombroski, J. L. D.; Freitas, J. D. B., Aroucha, E. M. M. Comparação de métodos de mensuração de área foliar para a cultura da melancia. Pesquisa Agropecuária Tropical, v.42, p.241-245, 2012. https://doi.org/10.1590/S198340632012000200016

Taiz, L.; Zeiger, E. Fisiologia vegetal. 5.ed. Porto Alegre: Artmed, 2013. 918p.

Tester, M.; Davenport, R. $\mathrm{Na}^{+}$tolerance and $\mathrm{Na}^{+}$transport in higher plants. Annals of Botany, v.91, p.503-527, 2003. https://doi. org/10.1093/aob/mcg058 